\title{
Multidermatomal herpes zoster
}

\author{
Deepak Sundriyal, ${ }_{1}^{1}$ Ruchi Kapoor, ${ }^{2}$ Naveen Kumar, ${ }^{3}$ Meenu Walia ${ }^{1}$
}

${ }^{1}$ Department of Medical Oncology, Dharamshila Hospital and Research Center, New Delhi, India ${ }^{2}$ Department of Anesthetist, North Delhi Municipal Corporation Medical College, New Delhi, India

${ }^{3}$ Department of Internal Medicine, P.G.I.M.E.R. \& Dr Ram Manohar Lohia Hospital, New Delhi, India

\section{Correspondence to}

Dr Naveen Kumar, docnaveen2605@yahoo.co.in

Accepted 12 May 2014

\section{DESCRIPTION}

A 37-year-old male patient with acute myeloid leukaemia presented to us with eruptive lesions over the anterior chest and neck for the past 5 days and severe burning pain over the involved areas. He had earlier received consolidation chemotherapy. On examination, he was afebrile. Multiple papular, vesicular and crusting lesions over C2 to C7 and T1 to T3 dermatomes were noted which were consistent with herpes zoster (HZ; figures 1 and 2). No ocular or neurological symptoms were present except the neuropathic pain. Oral valacyclovir therapy along with opioids and tricyclic antidepressants was started. His lesions resolved over a period of 2 weeks, however neuralgia persisted. Severity of pain was 6 (moderate) on numeric rating scale. He was advised capsaicin cream for topical application and oral pregabalin. He got good symptomatic relief with pain intensity measuring 2 (mild) 3 weeks later.

$\mathrm{HZ}$ or shingles is the clinical manifestation of the varicella-zoster virus (VZV). VZV can manifest in two ways namely, chickenpox and HZ. Chickenpox is a self-limiting illness usually seen in children and occurs due to primary infection. $\mathrm{HZ}$ occurs due to the reactivation of the latent VZV in dorsal root ganglia. The risk of $\mathrm{HZ}$ increases with old age and in patients with reduced cell-mediated immunity such as haematological malignancies, immunosuppressive therapies, HIV infection and transplant recipients. The incidence of $\mathrm{HZ}$ has been variably reported as $2 \%$ in chronic myeloid leukaemia, 13\% in chronic

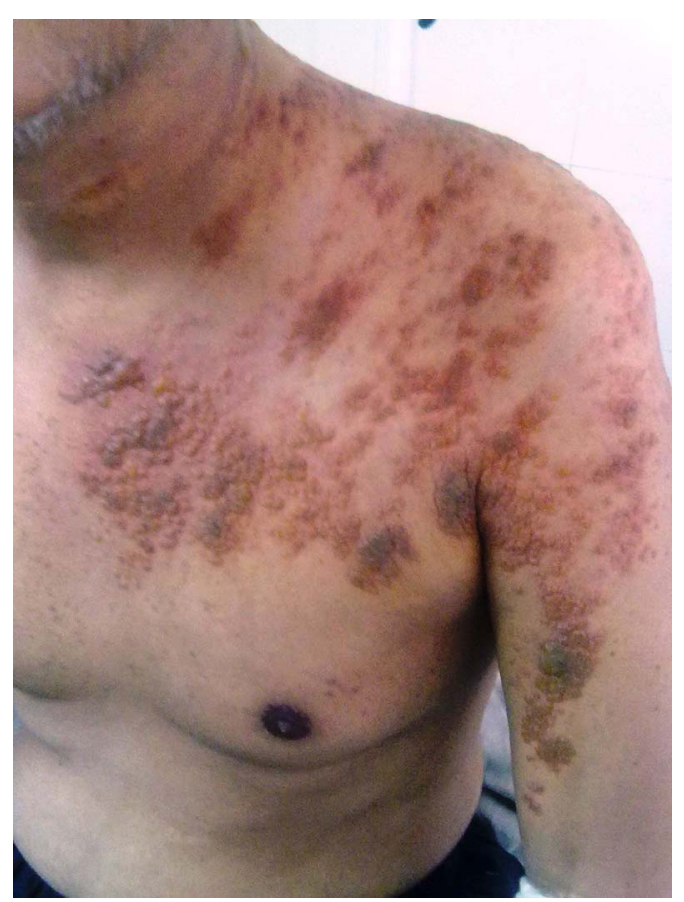

Figure 1 Multiple papular and vesicular lesions over left lower neck, anterior chest, upper and inner arm.

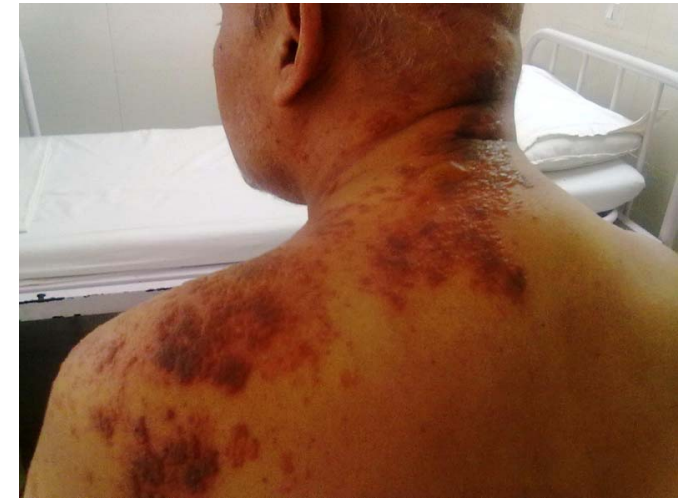

Figure 2 Posterior view showing papular and vesicular lesions over left side neck, shoulder and upper arm.

lymphocytic leukaemia and 30\% in marrow transplant recipients. ${ }^{1-3} \mathrm{HZ}$ occurring in these settings is usually very severe and may involve multiple contiguous, non-contiguous or bilateral dermatomes. It may be associated with encephalitis, pneumonitis, ocular complications and persistent postherpetic neuralgia. ${ }^{3}$ These patients require prompt diagnosis and early institution of antiviral therapy.

\section{Learning points}

- Extensive dermatomal involvement may be seen in herpes zoster $(\mathrm{HZ})$ occurring in the setting of immunodeficient conditions. Vice versa, an extensive involvement of $\mathrm{HZ}$ should prompt a clinician to search for associated immunodeficiency state.

- Patients may develop non-cutaneous complications and must be treated aggressively.

Contributors DS and NK contributed in the management of the patient, conceptualisation of the manuscript, data acquisition, manuscript drafting and revision, and gave final approval. RK and MW contributed in the management of the patient, conceptualisation of the manuscript, revision and gave final approval.

Competing interests None.

Patient consent Obtained.

Provenance and peer review Not commissioned; externally peer reviewed.

\section{REFERENCES}

1 Keating MJ, O'Brien S, Lerner S, et al. Long-term follow-up of patients with chronic lymphocytic leukemia(CLL) receiving fludarabine regimens as initial therapy. Blood 1998;92:1165-71.

2 Mattiuzi GN, Cortes JE, Talpaz M, et al. Development of varicellazoster virus infection in patients with chronic myelogenous leukemia treated with imatinib mesylate. Clin Cancer Res 2003;9:976-80

3 Locksley RM, Flournoy N, Sullivan KM, et al. Infection with varicella-zoster virus after marrow transplantation. $J$ Infect Dis 1985;152:1172-81. 


\section{Images in...}

Copyright 2014 BMJ Publishing Group. All rights reserved. For permission to reuse any of this content visit http://group.bmj.com/group/rights-licensing/permissions.

BMJ Case Report Fellows may re-use this article for personal use and teaching without any further permission.

Become a Fellow of BMJ Case Reports today and you can:

- Submit as many cases as you like

- Enjoy fast sympathetic peer review and rapid publication of accepted articles

- Access all the published articles

- Re-use any of the published material for personal use and teaching without further permission

For information on Institutional Fellowships contact consortiasales@bmjgroup.com

Visit casereports.bmj.com for more articles like this and to become a Fellow 